\title{
衛星搭載マイクロ波放射計を用いた薄水域の海水密接度推定に 水厚が及ぼす影響に関する研究
}

\section{A study of the influence of thin ice thickness in the calculation of sea ice concentration from satellite passive microwave data}

\author{
中山 雅茂*・長＼cjkstart幸平*・下田 陽久*・坂田 俊文* \\ 谷川 朋範** ・西尾 文彦*** \\ Masashige Nakayama, Kohei Cho, Haruhisa Shimoda, Toshibumi Sakata, \\ Tomonori Tanikawa and Fumihiko Nishio
}

\begin{abstract}
Ice concentration derived from satellite passive microwave sensor data is a key parameter for monitoring the global sea ice cover areas. Since the sea surface heat flux is quite sensitive to the existence of thin ice, accurate calculation of ice concentration within thin ice area is very important for heat exchange between ocean and atmosphere. In this study, two sea ice concentration algorithms, namely NASA Team algorithm and Bootstrap algorithm, were compared for the thin sea ice area of the Okhotsk Sea to evaluate the effect of sea ice thickness to the calculation of ice concentration from SSM/I data. Firstly, 100\% sea ice concentration areas were extracted by using simultaneously collected NOAA/AVHRR/2 data. Then the ice concentrations of those areas were calculated with using SSM/I. The result shows that the NASA Team algorithm was likely to underestimate the ice concentration within the $100 \%$ thin ice area. The ice thickness of those areas was estimated with using AVHRR/ 2 data, and they were compared with the measured brightness temperatures of each SSM/I channels. It has become clear that the wavebands of $19 \mathrm{GHz}$ and $37 \mathrm{GHz}$ at horizontal polarization were sensitive to the thickness of thin ice. This explains why ice concentrations of thin ice area were underestimated with the NASA Team algorithm.
\end{abstract}

\section{1.はじめに}

走査型の衛星搭載マイクロ波放射計による全球観測 は，米国航空宇宙局 (NASA)が1972年12月に Nimbus

* 東海大学情報技術センター

Tokai University Research and Information Center

T151-0063 東京都渋谷区富ヶ谷2-28-4

2-28-4, Tomigaya, Shibuya, Tokyo, 151-0063

** 筑波大学大学院生命環境科学研究科

Graduate School of Life Environmental Sciences,

Tsukuba University

テ305-8571 茨城県つくば市天王台1-1-1

1-1-1, Tennoudai, Tsukuba, Ibaraki, 305-8571

***千葉大学環境りモートセンシング研究センター

Center for Environmental Remote Sensing, Chiba University

厂263-8522 千葉県千葉市稲毛区弥生町1-33

1-33, Yayoi, Inage, Chiba, 263-8522

「写真測量とリモートセンシング」VOL. 40, NO. 5, 2001
- 5 に搭載し打ち上げた観測周波数 $19.3 \mathrm{GHz}$ 带の ESMR (Electrically Scanning Microwave Radiometer)によって始められた。ESMR による観測は1976 年まで行われた ${ }^{1)}$ 。その後, 1978年に Nimbus- 7 に搭載 された多チャンネルのマイクロ波放射計 SMMR (Scanning Multichannel Microwave Radiometer) によって観測が再開し, 現在は DMSP(Defense Meteorological Satellite Program) に搭載された SSM/I (Special Sensor Microwave/Imager) によって観測 が続けられている2。

衛星搭載マイクロ波放射計は太陽光を必要とせず, また波長带によって雲による影響が少なく，さらに海 氷の分布する極域全体を一日で観測することができ， 既に22年間の連続したデータセットがある。可視・近 赤外センサやSAR よる海水分類などの研究は行われ ているが，可視・近赤外センサによる観測は天候の影 響を受けやすく, SAR は過去に遡った海水分布の時系 列解析を行うのに十分なデータセットが存在しない。 
このようなことから，広域な海水分布の変動把握には 衛星搭載マイクロ波放射計が有効である。しかし，そ の観測データから海水密接度を推定する既存の手法で は，一年氷の中でも成長段階の若い薄水域で推定值の ばらつきが大きくなることが指摘されている31,4)。この ことは, 薄水域に扔ける海水の厚さの違いが, 海水密 接度の推定に影響を与えている可能性を示唆してい る。また, Maykut ${ }^{5}$ は, 海水表面から大気への熱輸送 量が氷厚 $40 \mathrm{~cm}$ 以下の海水は水厚 $1 \mathrm{~m}$ 以上の海水に比 べ, 10１00倍大きいことをモデルで示しており，薄水 域の観測は海洋と大気間の熱収支を考える上でも重要 である。

一方，才ホーツク海は低緯度にある季節海水域とし て知られ，薄氷域が形成されやすい。また，1978年か ら1996年までの衛星搭載マイクロ波放射計デー夕を用 いた解析結果から，オホーツク海の海水の減少傾向が 報告されているが6),7)，近年は増加傾向を示( ${ }^{8)}$ その変 動が注目されている。以上のような背景から本研究で はオホーツク海の薄水域を対象に, 既存の代表的な衛 星搭載マイクロ波放射計を用いた海水密接度推定手法 である，NASA Team algorithm と Bootstrap algorithm が水の厚さの違いによってどのような影響を受 けるのかを, NOAA/AVHRR/ 2 デー夕を用いて詳細 に検討した。なお，本研究では水厚が $30 \mathrm{~cm}$ 未満の水を 薄水と呼ぶことにする。

\section{2. 既存の海水密接度推定アルゴリズム}

これまでに衛星搭載マイクロ波放射計を用いた海水 密接度推定アルゴリズムは各種提案されている が9 17), 中でも定評があるのが米国の NSIDC (National Snow and Ice Data Center) の海水デー夕 セット ${ }^{18), 19}$ に採用されている, Cavalieri らが開発し た NASA Team algorithm(10),12,13) と Comiso らが開

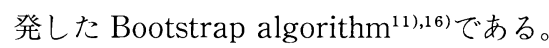

\subsection{NASA Team Algorithm}

NASA Team algorithm ${ }^{10), 12), 131}$ は, 開放水面, 一年 水, 多年水の各周波数, 偏波に扔ける放射率の違いを 利用する。開放水面に比べ一年水, 多年水の放射率の 差が, $19 \mathrm{GHz}$ 帯の水平偏波と垂直偏波で小さい。一方, $37 \mathrm{GHz}$ 帯と $19 \mathrm{GHz}$ 帯の垂直偏波に挑ける放射率の差 が，一年水の場合には 0 に近く，それに比べ多年水の $-40-$
場合には負の值になる ${ }^{10)}$ 。この二つの特徵を次に示す $P R$ (Polarization Ratio), GR (Gradient Ratio) と 定義した。

$P R=\frac{T B(19 V)-T B(19 H)}{T B(19 V)+T B(19 H)}$

$G R=\frac{T B(37 V)-T B(19 V)}{T B(37 V)+T B(19 V)}$

$T B(19 V): 19 \mathrm{GHz}$ 帯垂直偏波の観測輝度温度,

$T B(19 H): 19 \mathrm{GHz}$ 帯水平偏波の観測輝度温度,

$T B(37 \mathrm{~V}): 37 \mathrm{GHz}$ 帯垂直偏波の観測輝度温度, ここで, 一年水の海水密接度を $C_{F}$, 多年水の海水密接 度を $C_{M}$ とすると, センサで観測される輝度温度 $T B$ は次式で表せられる。

$T B=T B_{W} \cdot\left(1-C_{F}-C_{M}\right)+T B_{F} \cdot C_{F}+T B_{M} \cdot C_{M} \cdots$

$T B_{W}$ : 海水面の観測輝度温度,

$T B_{F}$ : 一年水の観測輝度温度,

$T B_{M}$ : 多年水の観測輝度温度,

$19 \mathrm{GHz}$ 帯水平・垂直偏波と $37 \mathrm{GHz}$ 帯の垂直偏波のそ れぞれについて, 式(3)を立て式(1), 式(2)に代大するこ とで, 海氷密接度 $C$ を次のように導くことができる。

$$
\begin{aligned}
C_{F}= & \frac{a_{0}+a_{1} \cdot P R+a_{2} \cdot G R+a_{3} \cdot P R \cdot G R}{c_{0}+c_{1} \cdot P R+c_{2} \cdot G R+c_{3} \cdot P R \cdot G R} \\
C_{M}= & \frac{b_{0}+b_{1} \cdot P R+b_{2} \cdot G R+b_{3} \cdot P R \cdot G R}{c_{0}+c_{1} \cdot P R+c_{2} \cdot G R+c_{3} \cdot P R \cdot G R} \\
& a_{n}, b_{n}, c_{n}: \text { 定数 }
\end{aligned}
$$$$
C=C_{F}+C_{M}
$$

図 1 a NASA Team Algorithmの概念図を示 す。灰色で示した特徵空間を利用して海水密接度の推 定を行う。しかし一年水の中でも成長段階の若い海水 は， $G R$ の值がほぼ一定で $P R$ の值が成長段階によっ て変化することが一年氷の多いべーリング海の観測結 果から明らかになり，薄水検出のために図 $1 \mathrm{a}$ に黒色 で示した特徴空間が提案されている ${ }^{15)}$ 。本研究では前 者をNASA Team Standard Algorithm, 後者を NASA Team Thin Ice Algorithm と呼び，それぞれ NASA-St., NASA-Thin と表記する。図 1 b に北半 球の観測值を灰色，オホーツク海のみの観測值を黒色 で示した。

NASA-St. と NASA-Thin は, PR vs. GR の特徵空 間上（図 1 a) で, 多年水の存在する場合と存在しない 場合で使い分ける。そのため, 季節海氷域以外で NASA-Thin を使うと, 多年水の海水密接度を推定で きない。逆に, 季節海水域以外では NASA-St. を使う 


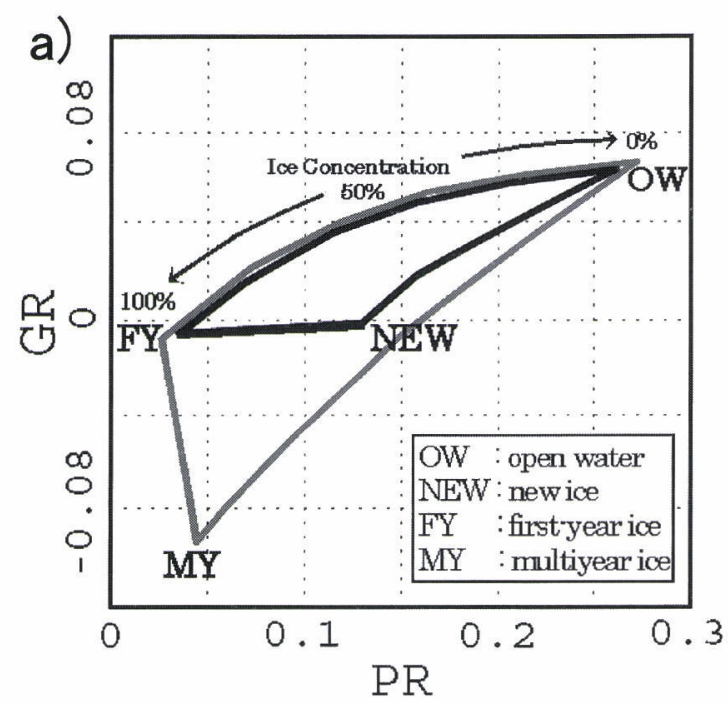

a ) アルゴリズムの概念図

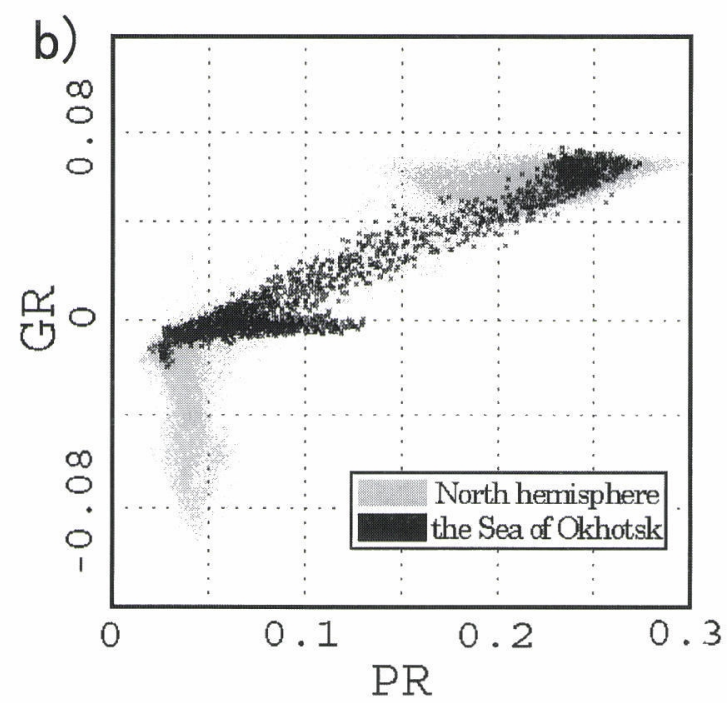

b) 1998年 2 月 17 日の SSM/I データより求めた北半球 (グ レー色）とオホーツク海 (黒色) のPR vs. GR の分布

図 1 NASA Team algorithm の説明

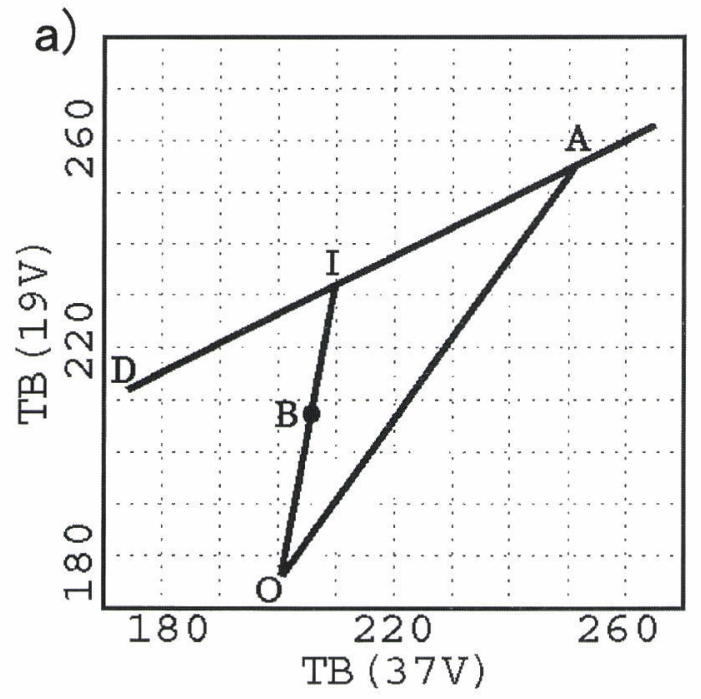

a) アルゴリズムの概念図

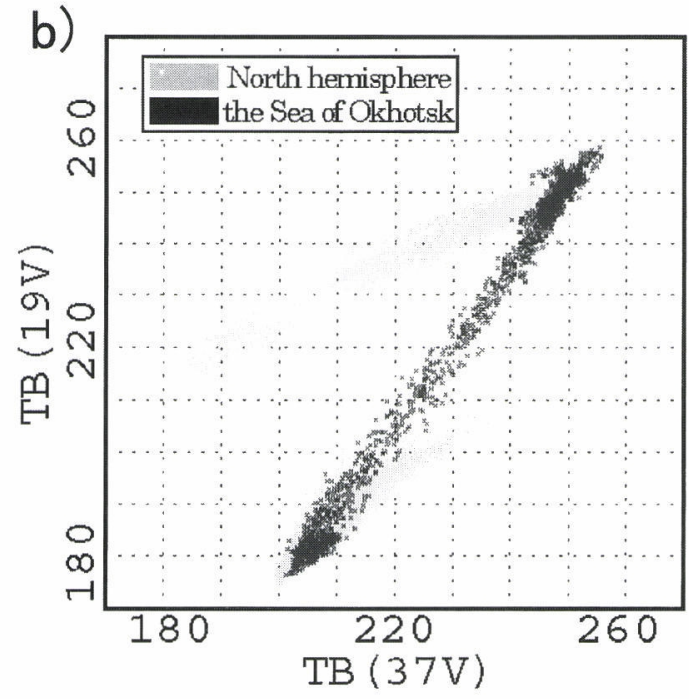

b) 1998年 2 月 17 日の SSM/I データより求めた北半球 (グ レー色）とオホーツク海（黒色）の輝度温度の分布

図 2 Bootstrap algorithm の説明

ことになりそそこに薄氷が存在した場合は海水密接度 を過小評価することになる。

多年水の存在しないオホーツク海で, NASA-Thin によって一年水と新生水の混合率を求女，熱フラック 又を推定した研究20)や, $P R$ の值に閾值処理を行うこ とで薄水の分類を行い, 熱フラックスの推定を行った ノースウォータでの研究 ${ }^{21) な と ゙ か ゙ あ る 。 し か し な か ゙ ら ~}$
いずれも, 海水密接度推定值や $P R$ の值に及ぼす薄水 の水厚依存性に関する十分な評価は行っていない。

\subsection{Bootstrap Algorithm}

Bootstrap Algorithm (以後, Boot と表記) 11),16)は一 年水の存在する海水域で $19 \mathrm{GH} z$ 带の垂直偏波と 37 $\mathrm{GHz}$ 帯の垂直偏波を用いて海水密接度を推定する。 
Bootの概念図を図 2 a に示す。図 2 a の O は開放水 面， $\mathrm{A}$ は一年水，Dは多年水にそれぞれ対応する。こ の手法は多年水と一年水の混在する海水密接度 $100 \%$ の輝度温度は $\mathrm{AD}$ を結ぶ直線上に分布することを利 用している。任意の観測点の輝度温度を $\mathrm{B}$ とすると， $\mathrm{O}$ と $\mathrm{B}$ を結ぶ直線と直線 $\mathrm{AD}$ の交点 $\mathrm{I}$ を求め, 線分 $\mathrm{OI}$ に対する線分 $\mathrm{OB}$ の内分比から海水密接度を求め るというものである。一年水だけで構成される海水域 では海水密接度 $100 \%$ の場合が A に対応し, 開放水面 の割合が増えるとともに $\mathrm{O}$ 側へ移動することになる。 図 $2 \mathrm{~b}$ に北半球の観測値を灰色, オホーツク海のみの 観測值を黒色で示した。

\section{3. 解析データとテストサイト}

本研究では DMSP 衛星に搭載されたマイクロ波放 射計 SSM/I のデータを用いて, 薄水域における前記 2 つの海水密接度推定アルゴリズムの比較・評価を 行った。評価にあたっては, NOAA 衛星に搭載された 可視赤外センサ AVHRR/ 2 のデータを用いて海水厚 を推定した。両センサの諸元と SSM/Iによる各海水 密接度推定アルゴリズムで海水密接度を計算する際に 使用したパラメータを表 1 に示す。使用したデー夕は 1998年 2 月17日に観測されたものである。なお, SSM/ I データは NSIDCにより配布されている $25 \mathrm{~km} \times 25$ $\mathrm{km}$ グリッドのポーラーステレオ座標に投影された データを使用した ${ }^{22)}$ 。AVHRR/ 2 は SSM/Iに比べ分

表 $1 \mathrm{NOAA} / \mathrm{AVHRR} / 2$, DMSP/SSM/I と SSM/I による各海水密接度 推定アルゴリズムのパラメータの諸元

a ) NOAA/AVHRR/ 2 の諸元

\begin{tabular}{c|c|c}
\hline Channel & 観測波長帯 $(\mu \mathrm{m})$ & 空間分解能 $(\mathrm{km})$ \\
\hline 1 & $0.58-0.68$ & \\
2 & $0.725-1.10$ & \\
3 & $3.55-3.93$ & 1.1 \\
4 & $10.30-11.30$ & \\
5 & $11.50-12.50$ & \\
\hline
\end{tabular}

b ) $\mathrm{DMSP} / \mathrm{SSM} / \mathrm{I}$ の諸元

\begin{tabular}{c|c|c}
\hline 観測中心周波数 $(\mathrm{GHz})$ & 観測偏波 & 空間分解能 $(\mathrm{km})$ \\
\hline 19.35 & 水平 $/$ 垂直 & $70 \times 45$ \\
22.23 & 垂直 & $60 \times 40$ \\
37.0 & 水平 $/$ 垂直 & $38 \times 30$ \\
85.5 & 水平 $/$ 垂直 & $16 \times 14$ \\
\hline
\end{tabular}

c）各海水密接度推定アルゴリズムのパラメータ

\begin{tabular}{|c|c|c|c|}
\hline \multicolumn{4}{|c|}{ Coefficients of NASA Team Standard algorithm ${ }^{13)}$} \\
\hline$a_{0}=3286.56$ & \multicolumn{2}{|c|}{$\mathrm{b}_{0}=-790.321$} & $\mathrm{c}_{0}=2032.20$ \\
\hline$a_{1}=-20764.9$ & \multicolumn{2}{|c|}{$b_{1}=13825.8$} & $\mathrm{c}_{1}=9241.50$ \\
\hline $\mathrm{a}_{2}=23893.1$ & \multicolumn{2}{|c|}{$b_{2}=-33104.7$} & $c_{2}=-5655.62$ \\
\hline $\mathrm{a}_{3}=47944.5$ & \multicolumn{2}{|c|}{$b_{3}=-47720.8$} & $c_{3}=-12864.9$ \\
\hline \multicolumn{4}{|c|}{ Coefficients of NASA Team Thin Ice algorithm ${ }^{40)}$} \\
\hline $\mathrm{a}_{0}=1255$ & \multicolumn{2}{|c|}{$\mathrm{b}_{0}=687$} & $c_{0}=-721$ \\
\hline$a_{1}=-10996$ & \multicolumn{2}{|c|}{$\mathrm{b}_{1}=600$} & $c_{1}=12936$ \\
\hline$a_{2}=18679$ & \multicolumn{2}{|c|}{$b_{2}=3417$} & $c_{2}=-31260$ \\
\hline$a_{3}=30929$ & \multicolumn{2}{|c|}{$b_{3}=3504$} & $c_{3}=-44918$ \\
\hline \multicolumn{4}{|c|}{ Bootstrap algorithm ${ }^{16)}$} \\
\hline \multicolumn{2}{|c|}{$\begin{array}{l}\text { 1. } 100 \% \text { ice (line } \mathrm{AD} \text { ) } \\
\text { Slope of line } \mathrm{AD}=0.553 \\
\text { Offset of line } \mathrm{AD}=117.0\end{array}$} & \multicolumn{2}{|c|}{$\begin{array}{l}\text { 2. Open water tie-point } \\
19 \mathrm{GHz} \mathrm{V}-\mathrm{pol}=179 \mathrm{~K} \\
37 \mathrm{GHz} \mathrm{V}-\mathrm{pol}=202 \mathrm{~K}\end{array}$} \\
\hline
\end{tabular}


a)

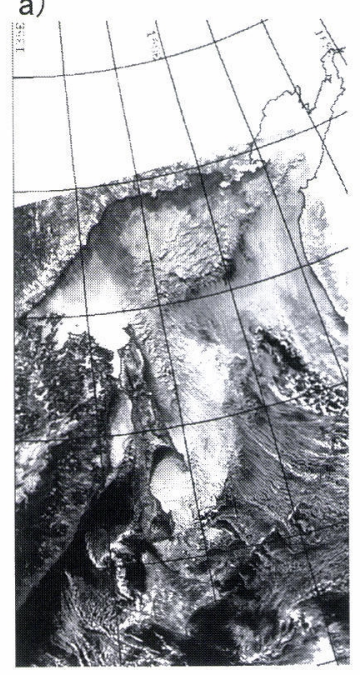

b)

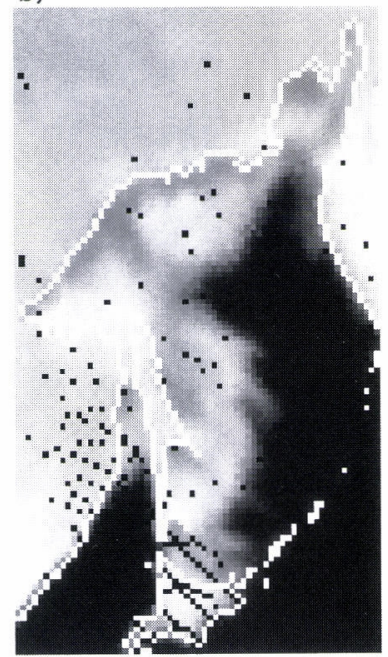

図 3 解析対象領域と使用した AVHRR/ 2 画像と SSM/I 画像

a) 1998年 2 月17日のオホーツク海をとらえたNOAA/ AVHRR/ 2 画像。

b ) 1998年 2 月17日のオホーツク海をとらえた SSM/I 19 $\mathrm{GHz}$ 帯水平偏波画像。黒から白になるほど輝度温度が 高くなる。海岸線は白色にした。

解能が 1 桁以上高く，快晴時のデー夕を用いれば $\mathrm{SSM} / \mathrm{I}$ での海水の密接度, 厚さを推定する際の良い検 証データとなる(詳しくは後述)。また，テストサイト としては, 季節海氷域で薄水域が形成されやすい才 ホーツク海とした。解析対象域の AVHRR/ 2 画像お よびSSM/I画像を図 3 に示す。

\section{4. 解析方法}

\section{1 解析のフロー}

本研究の解析のフローを図 4 に示す。SSM/I デー夕 を用いた海水密接度推定における薄水の水厚の影響を 実際の海水密接度変化と切り離して評価するために は, 海水密接度が $100 \%$ の均一な海水域を対象とする必 要がある。そこで, まず，対象域の AVHRR/2 と $\mathrm{SSM} / \mathrm{I}$ のデー夕を幾何学的に重ね合わせ, AVHRR/ 2 画像上から海水密接度 $100 \%$ の海水域を抽出した。次 にAVHRR/ 2 画像上で海水密接度が $100 \%$ となった 海水域が, SSM/Iから NASA-St., NASA-Thin およ び Bootで求めた海水密接度ではどうなるかを評価し た。さにそれらの領域の SSM/I の各観測周波数 帯・偏波の輝度温度特性を調べた。また，それらの海 水域の水厚を AVHRR/ 2 デ一タから推定し, 水厚が

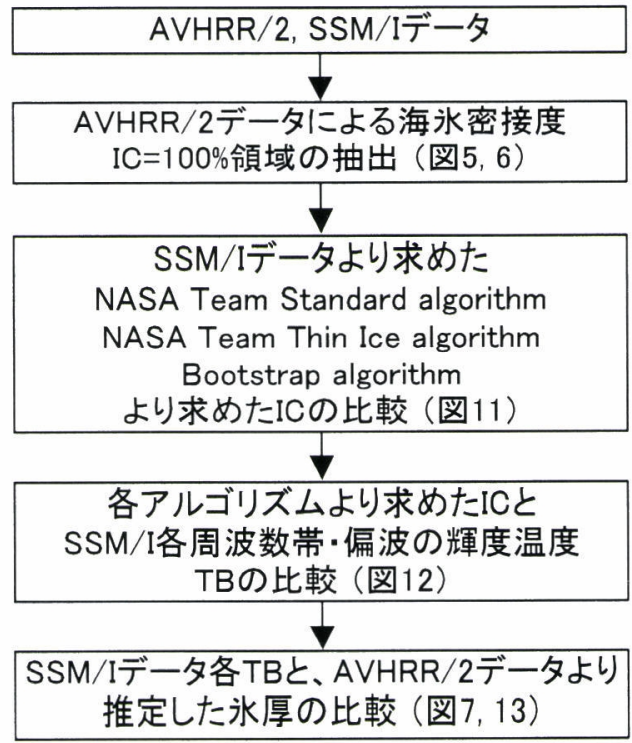

図 4 解析のフロー

海水密接度にどのような影響を与えるかを評価した。

以下に, AVHRR/2 データを用いた海水密接度 $100 \%$ 領域の抽出方法, およびAVHRR/ 2 データによ る海水厚推定手法について説明する。

\section{2 密接度 $100 \%$ 領域の抽出}

オホーツク海を観測したAVHRR/ 2 データを用い て,海水密接度100\%と推定される海水域の抽出を行っ た。先に示した図 3 a が解析に使用した1998年 2 月 17 日の AVHRR/ 2 画像である。処理フローを図 5 に示 के。

まず, NOAA POLAR ORBITER DATA USERS $\mathrm{GUIDE}^{23)}$ に示された手順に基づき放射輝度補正を行 い Channel 1，2 は反射率, Channel 3，4，5 は温度 に変換した。Channel 1, 2 については太陽天頂角 $\theta$ の 違いによる, 地表面への入射光量が変化する影響を取 り除くために $\cos \theta$ にるる補正を行った。さらに海水 の表面温度（IST：ice surface temperature）を split window 法によって Massom and $\mathrm{Comiso}^{24)}$ が求めた 回帰式より求めた。そして, SSM/I データと同じポー ラーステレオ座標系に $1.25 \mathrm{~km} \times 1.25 \mathrm{~km}$ の解像度で 投影変換を行った。

AVHRR/ 2 デー夕による雪水面上の雲域抽出は, 可 視, 近赤外の Channel 1, Channel 2 のデータだけで行 うのは雲と海水のアルベドが高いことから難しい。そ こで, Yamanouchi and Kawaguchi ${ }^{25)}$ が行った Chan- 


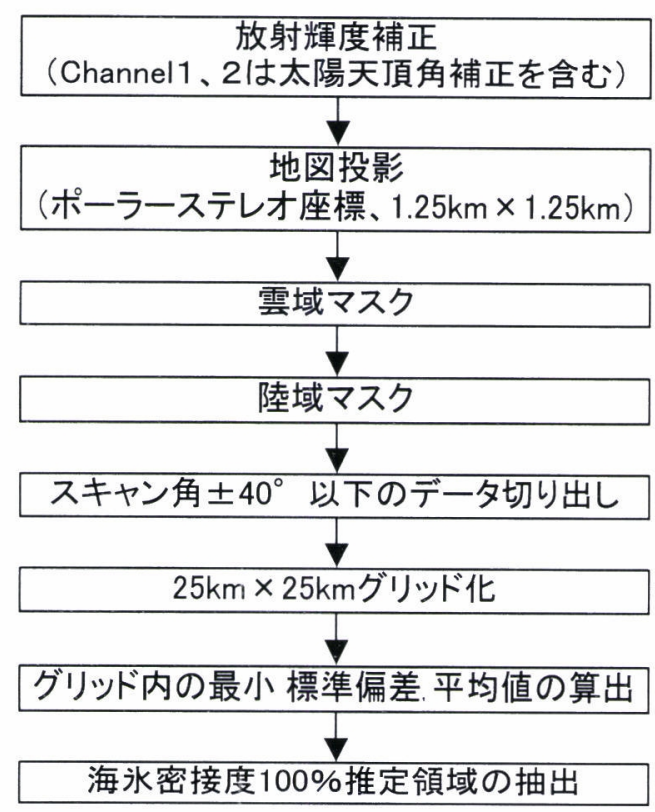

図 5 NOAA/AVHRR/ 2 データの処理フロー

nel 3 と Channel 4 の差を利用することによって, 雲域 の抽出を行った。雲域抽出によって, 雲域マスク処理 を行い,さらに陸域マスク処理を行うことで晴天域の 海水域デー夕を作成した。また AVHRR/ 2 センサは スキャン角 \pm 55.4 度と広いことから，オフナディアに なるほど方向性反射の影響を強く受け神), また, 光路長 が長くなりエアロゾルなどの大気の影響が大きくなる ので27)，スキャン角 $\pm 40^{\circ}$ 以下のデー夕のみを解析に使 用した。

$\mathrm{SSM} / \mathrm{I}$ データ $25 \mathrm{~km} \times 25 \mathrm{~km}$ と比較するため，ポー ラーステレオ座標に投影されたAVHRR/2 1.25 $\mathrm{km} \times 1.25 \mathrm{~km}$ データを 1 グリッド $25 \mathrm{~km} \times 25 \mathrm{~km}$ とし て, Channel 1, Channel 2 と IST の各グリッド内 $20 \times$ 20画素の最小值 (MIN), 標準偏差 (STDEV), 平均值 (AVE)を計算した。最後に次の条件式を全て満たした 場合に, 均一な海水で完全に覆われた海水密接度 $100 \%$ 推定域として抽出を行った。

Channel 1 (MIN) $>10$

Channel 1 (STDEV) $<5$

Channel 2 (STDEV $)<4$

IST $(\mathrm{STDEV})<0.4$

海水密接度100\%領域として推定された海水域を図 6 に示す。

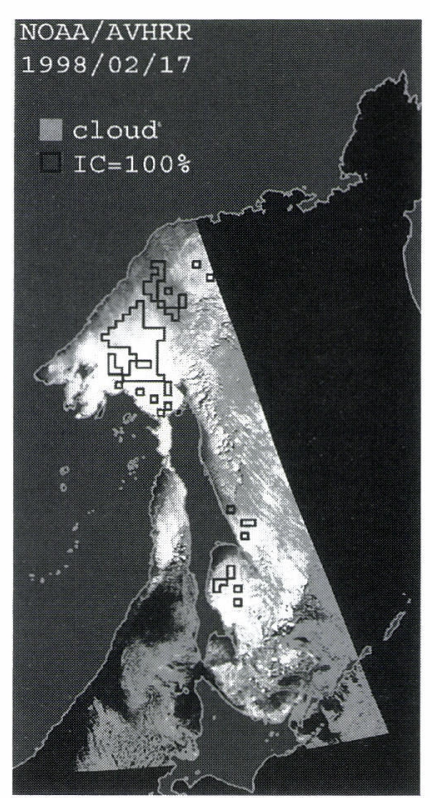

図 6 NOAA/AVHRR/ 2 データによって海水密接度100\% 領域として推定された海水域

\subsection{AVHRR データによる海水厚の推定}

(1) 既存の手法

広範囲の海水厚の観測は，潜水艦や海底に係留され た音響ソナー ${ }^{28), 29}$ による水面下からの海水の喫水部 の測定や，航空機や船舶に搭載したレーザ一高度計に よる海水の水面より上部の高さの測定，ビデオカメラ やデジタルカメラを用いて砕水船が進む際に海水の破 断面を撮影する方法などが行われている30),31)。近年で は船舶からレーザー高度計と電磁誘導を組み合わせた

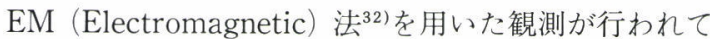
いる。しかし，いずれの方法も SSM/I の分解能を力 バーする領域で観測することは難しく，さらに，本研 究で対象としている薄水の測定を行うことができてい ない。

(2) AVHRR データによる推定手法

AVHRR/ 2 の観測波長带における海水の反射率に 関する実験は多くなされており，Massom and Comis$\mathrm{O}^{24)}$ は AVHRR/ 2 デー夕を用いて海水分類を行って いる。その論文中 ${ }^{24)}$ でAVHRR/ 2 Channel 1, Channel 2 の波長帯における海水の反射率を, 海水の種類や 厚さ，状態，観測条件ごとにいくつかの文献 ${ }^{33), 34), 35) を ~}$ 元にまとめられている。海水上に積雪が無い場合の AVHRR/ 2 Channel 1, Channel 2 の波長帯における 海水厚と反射率の值について表 2 にまとめた。表 2 よ 
表 2 積雪のない海水についての水厚と NOAA/AVHRR Channel 1，2 2 の波長帯における反射率の関係

\begin{tabular}{|c|c|c|c|c|}
\hline Ice thickness $(\mathrm{cm})$ & average $(\mathrm{cm})$ & Channel 1 & Channel 2 & Reference ${ }^{33), 34), 35)}$ \\
\hline 0 (open water, overcast) & 0 & 0.07 & 0.07 & Allison et al., [1993] \\
\hline 1 & 1 & 0.13 & 0.12 & Grenfell [1983] \\
\hline $2.0-2.5$ (overcast) & 2.25 & 0.12 & 0.09 & Allison et al., [1993] \\
\hline $3.7-4.0$ (variable skies) & 3.85 & 0.18 & 0.17 & Allison et al., [1993] \\
\hline 5 & 5 & 0.19 & 0.17 & Perovich and Grenfell [1982] \\
\hline $6.0-9.0$ (clear skies $)$ & 7.5 & 0.31 & 0.23 & Allison et al, [1993] \\
\hline 10 & 10 & 0.35 & 0.24 & Grenfell [1983] \\
\hline 15 & 15 & 0.38 & 0.24 & Perovich and Grenfell [1982] \\
\hline 20 & 20 & 0.43 & 0.24 & Perovich and Grenfell [1982] \\
\hline 25 & 25 & 0.55 & 0.25 & Grenfell [1983] \\
\hline 50 & 50 & 0.62 & 0.25 & Grenfell [1983] \\
\hline 100 & 100 & 0.64 & 0.25 & Grenfell [1983] \\
\hline 300 & 300 & 0.64 & 0.25 & Grenfell [1983] \\
\hline
\end{tabular}

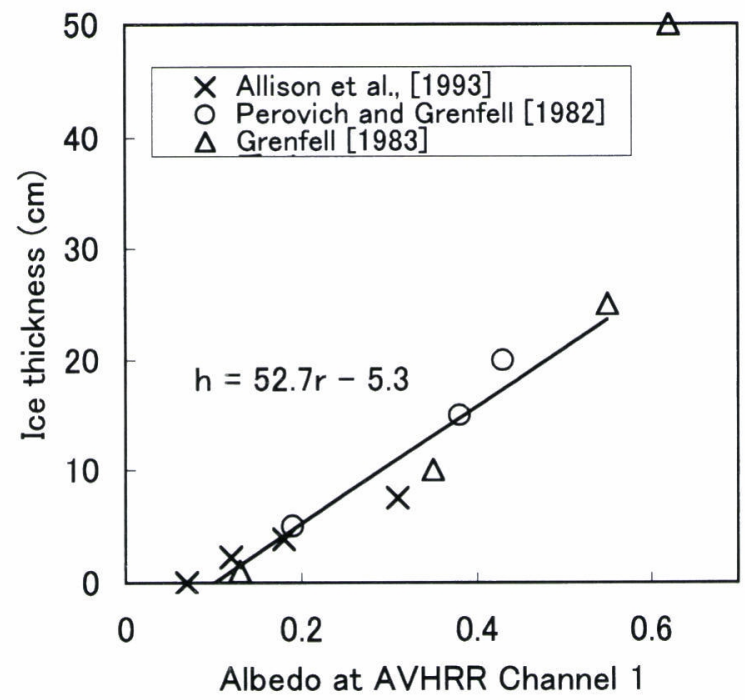

図 7 積雪のない水厚 $30 \mathrm{~cm}$ までの海水厚と AVHRR/ 2 Channel1の反射率の関係

ク近赤外域の波長帯である Channel 2 では，水厚が10 $\mathrm{cm}$ 以上になると反射率の変化がほとんどなくなるこ とがわかる。一方，可視域の波長帯である Channel 1 では氷厚 $25 \mathrm{~cm}$ まで水厚の増加とともに反射率が高く なっている。そして, 水厚 $50 \mathrm{~cm}$ 以上で反射率の変化が 少なくなることが分かる。図 7 に表 2 の氷厚 $25 \mathrm{~cm}$ ま での水厚とChannel 1 の反射率の関係を示した。海水

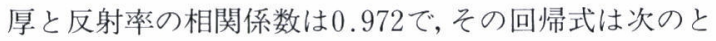
おりである。

$h=52.7 r-5.3(\mathrm{~cm})$

ここで $h$ は海水厚 (単位は $\mathrm{cm}$ ), $r$ は AVHRR/ 2 Channel 1 の波長带の反射率に対応子る。

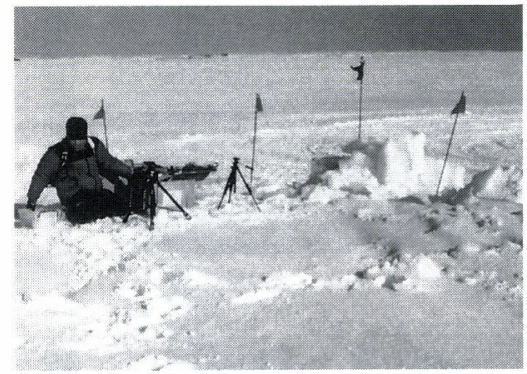

図 8 サロマ湖上プールでの薄氷スペクトル観測風景

$\mathrm{WMO}$ の海水分類の定義では氷厚 $10 \mathrm{~cm}$ 未満の海水 をニラス (nilas), 水厚 $10 \sim 30 \mathrm{~cm}$ 未満の海水を板状軟 水 (young ice), 水厚 $30 \mathrm{~cm}$ 以上を一年水 (first-year ice）と定義している ${ }^{36)}$ 。式(7)は氷厚 $25 \mathrm{~cm}$ 以下のデータ をもとに求女られた式であるが, 本研究では氷厚 $30 \mathrm{~cm}$ までの推定に使用した。

（3）海水上の積雪と反射率の関係

ここで問題となるのが，海水面の積雪分布の影響で ある。薄水の反射率は海水上の積雪の有無によって大 きく変わる。海水は薄いにもかかわらず積雪により, 反射率が上昇することが考えられる。そこで筆者らは, 2001年 2 月にサロマ湖上で薄氷のスペクトル観測を 行った。北海道東部に位置するサロマ湖は，2つの湖 ロによってオホーツク海とつながっており, 湖に流入 する河川口付近を除いて湖水の塩分濃度は外洋の值に 近く, 湖水の塩分構造は外洋の海水に似ている。サ口 マ湖の湖水上に $2 \mathrm{~m} \times 2 \mathrm{~m}$ のプールを 2 つ作成し, 新 しく結水した薄水のスペクトルを積雪がある状態と, 積雪を取り除いた状態で測定した。測定風景を図 8 に 示す。測定には米国 ASD 社製FieldSpecFR 使用 

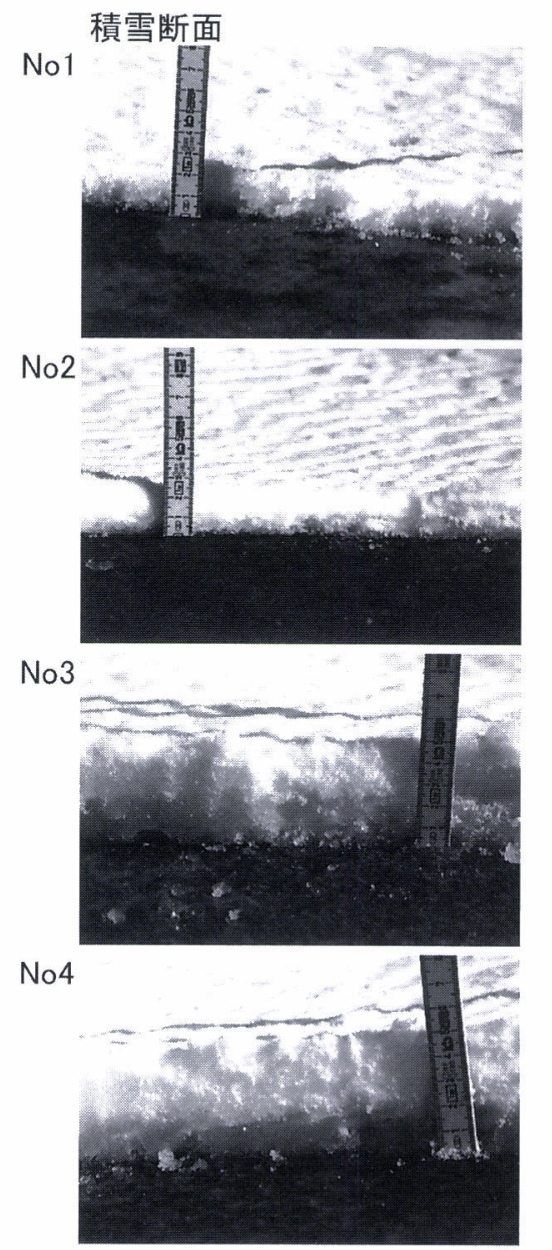

No5

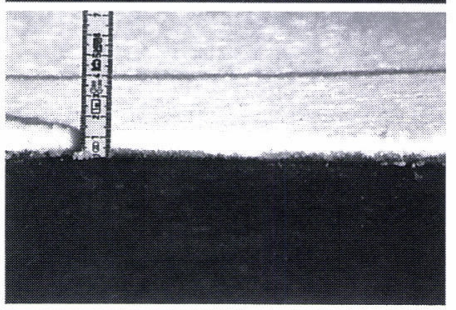

海永表面
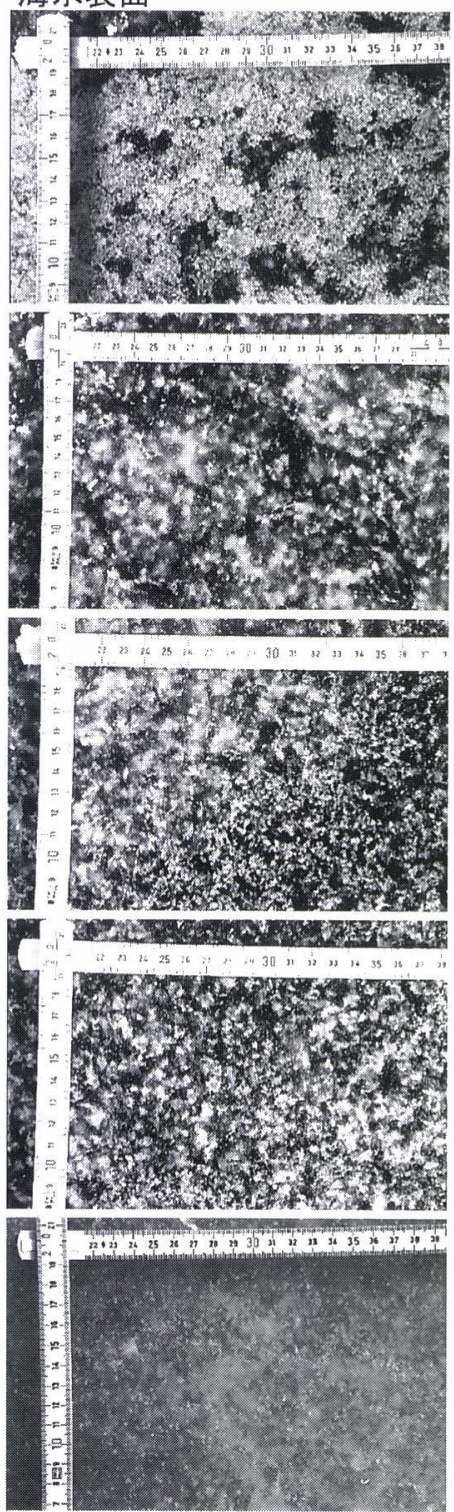

海水断面
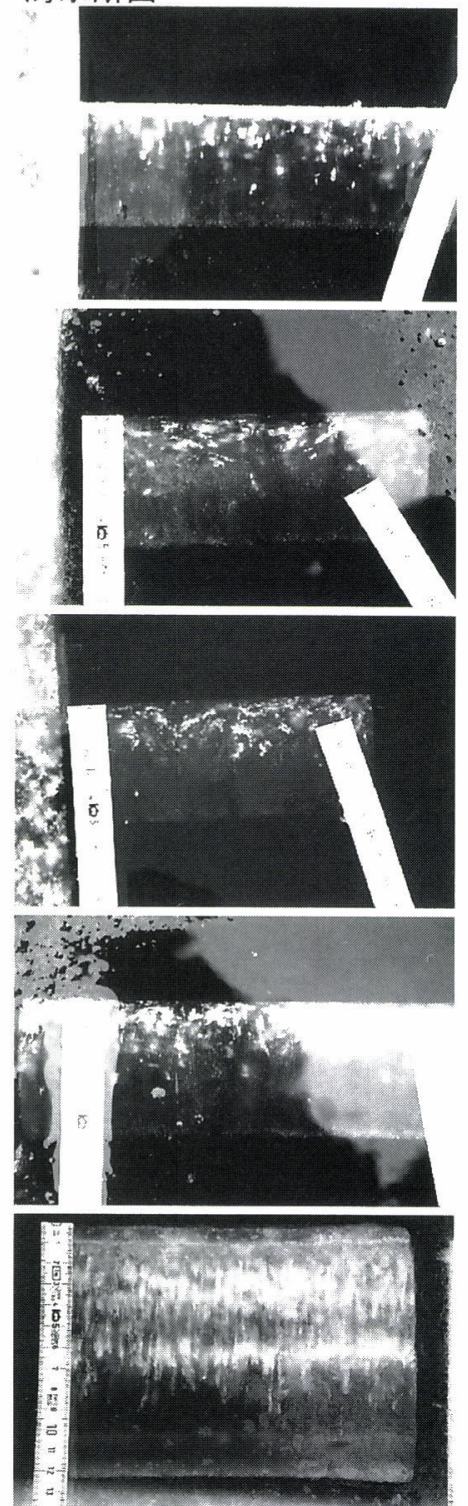

図 9 スペクトル観測を行った各地点の積雪断面, 海水表面, 海水断面の写真

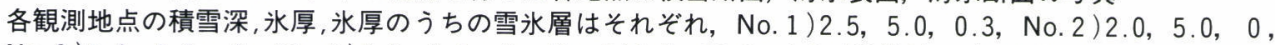
No. 3 ) 5.0, 5.0, 0, No. 4 ) 7.0, 5.0, 0, No.5) 1.5, 12.3, 1.0（単位は cm）であった。

L, 観測波長带 $(\lambda)$ が $0.35 \sim 2.5 \mu \mathrm{m}$, 波長分解能が $\lambda=$ $0.35 \sim 1.0 \mu \mathrm{m}$ で $3 \mathrm{~nm}, \lambda=1.0 \sim 2.5 \mu \mathrm{m}$ で10nm であ る。視野角 22 度, 湖水面からファイバーの先端までの 距離が約 $90 \mathrm{~cm}$ になるように設置した。そして湖水面 に対し水平に設置した標準白色板と対象物の放射束を 交互に20回測定し，それぞれの比を計算することで10 組のスペクトル反射率データを得た。この 10 組のスペ クトル反射率データの平均值を対象物の結果とした。
各観測地点の積雪断面, 積雪を取り除いた際の海水表 面，海水の垂直断面の写真を図 9 に，スペクトル観測 の結果を図10に示す。図 9 の観測地点番号と図10の凡 例の番号は対応している。図 10 から積雪深が約 $1.5 \mathrm{~cm}$ 以上存在すると, 可視域の波長帯の反射率は 0.8 以上と なることが確認できる。先に求めた式(7)で氷厚 $30 \mathrm{~cm}$ の時の反射率は約 0.67 となる。したがって海水上に海 氷を完全に覆うような積雪が存在した場合, 反射率は 


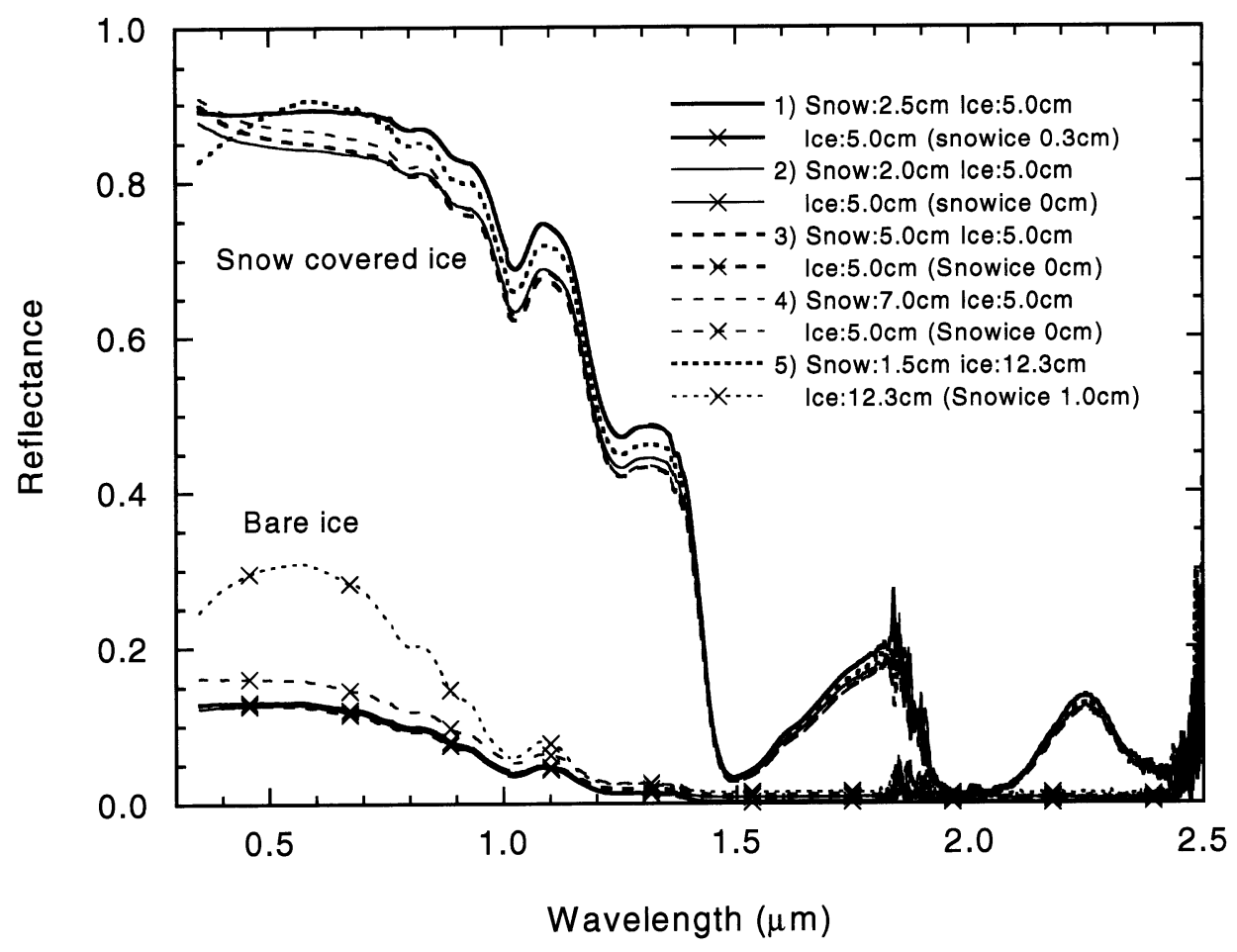

図10 薄水のスペクトル反射率

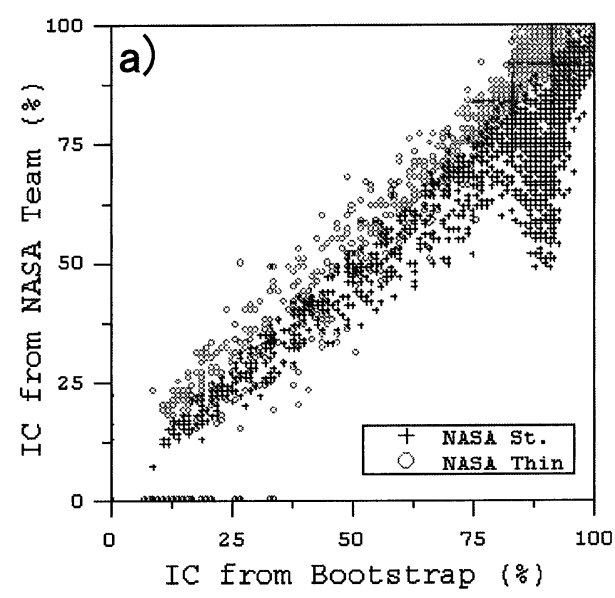

a ) オホーツク海全域の密接度推定値

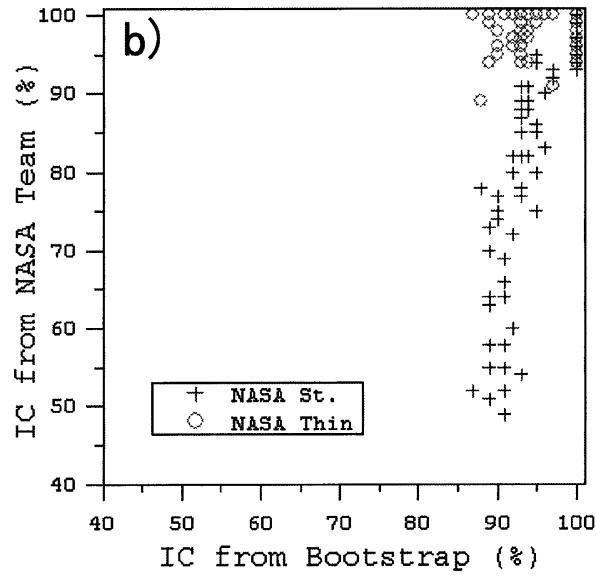

b ) NOAA/AVHRR/ 2 によって海水密接度 $100 \%$ として抽出された海水域の推定值

図11 各海永密接度推定アルゴリズムより求められた海水密接度推定值の比較

0.8 以上なるので水厚推定対象範囲外となり, 積雪の 無い薄水域と区別することができる。また，薄水上に 積雪深 $1 \mathrm{~cm}$ に満たない降雪があった場合は, 薄水表 面上の積雪が塩分濃度の高いブライン (塩水)を含み,

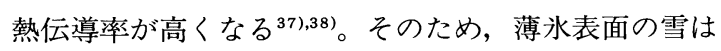
融けやすく, 可視域の反射率は海水表面の值に近づく と考えるのが妥当である。

\section{5. 結果と考察}

5.1 密接度 $100 \%$ 海永域におけるアルゴリズムの比較 AVHRR/ 2 デー夕を用いて抽出した海氷密接度 $100 \%$ 領域が，SSM/I デー夕を対象とした各海水密接 度推定アルゴリズムではどの程度の海水密接度に算定 
されたかを図11に示す。罒11aはオホーツク海全域の デー夕を示したものであり，図11bはそのうち AVHRR/ 2 データで海氷密接度 $100 \%$ 領域として抽出 されたデー夕を示した。図11aのオホーツク海全域で 見ると, Bootと NASA-Thin は0.976の高い相関を示 した。一方, Boot と NASA-St. では Boot で海水密接 度90\%以上の推定結果に対し, NASA-St. では大きな ばらつきが見られ，最も低いもので約 $50 \%$ となった。 また，図11bから AVHRR/ 2 で海水密接度 $100 \%$ とし て抽出された領域のみを対象とした場合に, NASASt. では海水密接度 $50 \%$ から $100 \%$ まで分布が連続的に 広がっていることがわかる。このことから，何らかの 理由により NASA-St. では海水密接度 $100 \%$ の領域の 海水密接度が低く見積もられていることがわかった。

\section{2 密接度推定值と輝度温度の比較}

AVHRR/ 2 データによって海水密接度 $100 \%$ として 抽出された領域における，各アルゴリズムの海水密接 度推定結果と $\mathrm{SSM} / \mathrm{I} の 19 \mathrm{GHz}, 37 \mathrm{GHz}$ 带，水平・垂 直偏波の輝度温度との関係を示したのが図12である。
この図から，垂直偏波の $19 \mathrm{GHz}$ 帯(図12c)，37GHz 帯 (図12d) で観測された輝度温度の変動幅が, 約 $10 \mathrm{~K}$ 以 下になっていることがわかる。この結果は中山ら ${ }^{39}$ が 報告した積雪の無い一年水の特性と合致している。一 方, 水平偏波では輝度温度が低くなると, NASA-St. で推定された海水密接度も低くなっていることがわか る(罒12a，b)。両者の関係は特に $19 \mathrm{GHz}$ 帯で顕著に 表れている。このことから, NASA-St. が他のアルゴ リズムに比べ海氷密接度を低く推定する原因は, 19 $\mathrm{GHz}$ 帯の水平偏波の輝度温度変化により $P R$ の值が 高くなっているためと考えられる。一方, Boot および NASA-Thinにおける海水密接度推定は垂直偏波の みに依存することから，このような水平偏波の影響は 表れていない。

\section{3 輝度温度と水厚の比較}

$\mathrm{SSM} / \mathrm{I}$ の $19 \mathrm{GHz}, 37 \mathrm{GHz}$ 带, 水平・垂直偏波によっ て観測された輝度温度の変化と, 薄水の水厚との関係 を図13に示した。薄水の水厚は式(7)をもとに0 30 cm について求めたものである。これから, 垂直偏波では
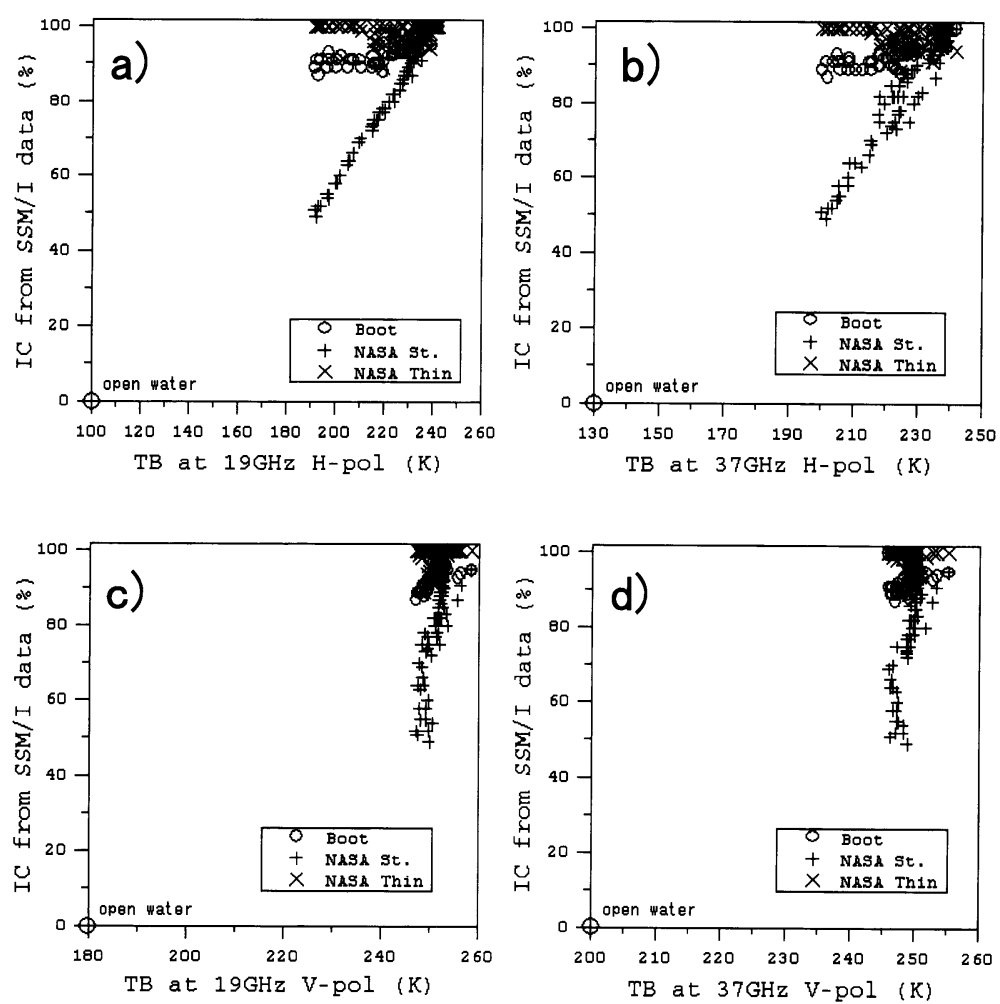

図12 SSM/I 19GHz, 37GHz 帯の水平・垂直偏波で観測された輝度温度と 各アルゴリズムによって推定された海水密接度の関係 

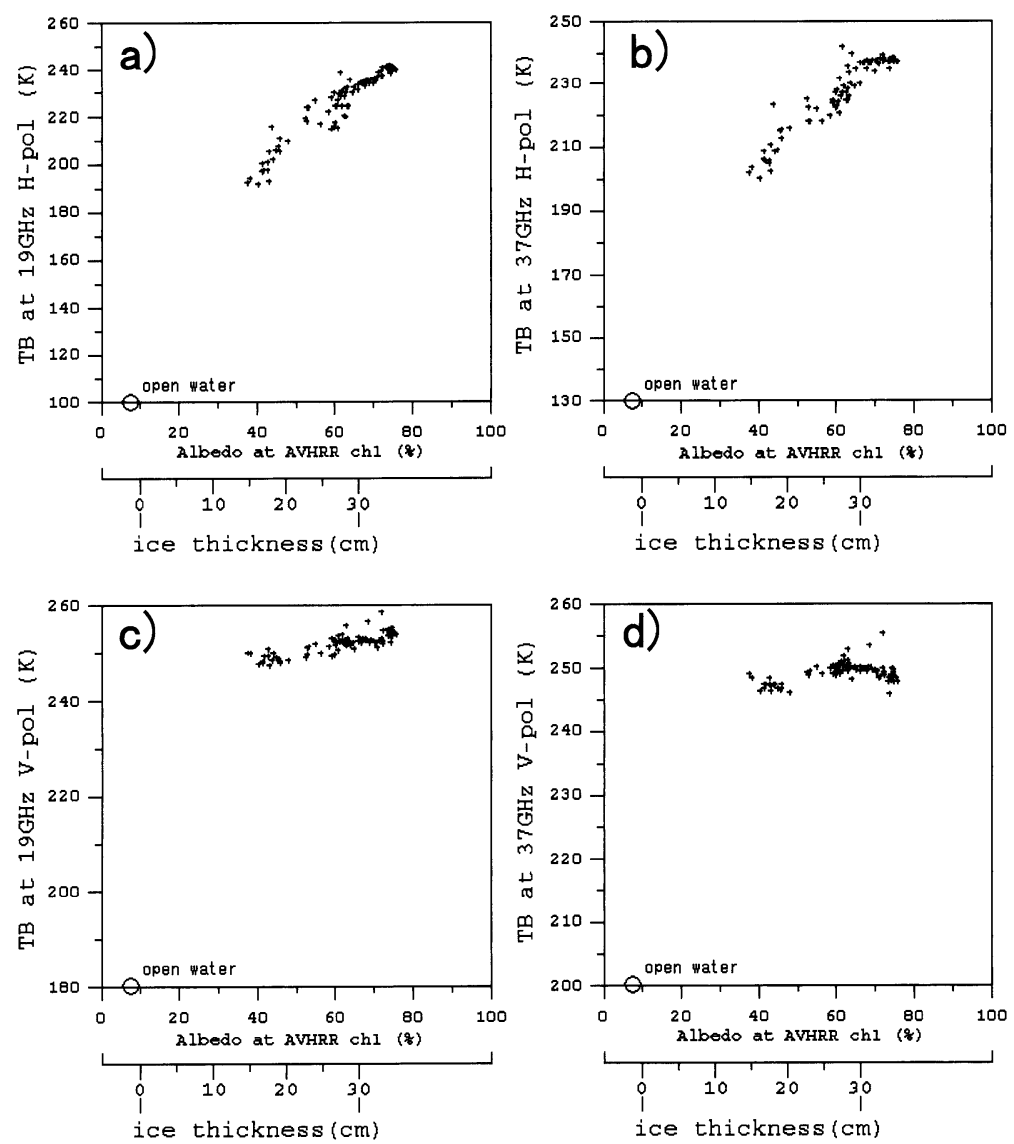

図13 SSM/I 19GHz，37GHz 帯の水平・垂直偏波で観測された輝度温度と NOAA/AVHRR/ 2 より推定された水厚の関係

水厚の変化に依存せずに輝度温度がほぼ一定であるの に対し(図13c，d)，水平偏波では水厚と輝度温度の変 化が正の相関になっている(図13a，b)。このことから， $19 \mathrm{GHz}$ 帯水平偏波で観測される薄水密接度 $100 \%$ の海 水域における輝度温度の低下は, 水厚が薄くなること によるものであり,これがNASA-St.における密接度 の低下をもたらしていることがわかった。

\section{6. まとめ}

オホーツク海の薄氷域を対象に, 既存の衛星搭載マ イクロ波放射計デー夕を用いた海水密接度推定アルゴ リズムにおける，薄水密接度推定に水厚が与える影響 について調べた。NOAA/AVHRR/ 2 デー夕を用いて $\mathrm{SSM} / \mathrm{I}$ データの一画素内が均一な海水で海水密接度 が100\%の領域の抽出を行い, 抽出された領域について 各アルゴリズムの比較を行った。その結果, NASA-St.
は Boot, NASA-Thin に比べ, 最大で約 $50 \%$ 低く海水 密接度を推定することが分かった。次に, 各アルゴリ ズムより計算された海氷密接度と SSM/I で観測され た輝度温度の比較を行うことで, 垂直偏波は海水密接 度推定結果に対する影響は少なく, 水平偏波は NASA -St.の場合においてその輝度温度の低下が海氷密接度 推定値を低くする要因であることがわかった。さらに, 各周波数・偏波の輝度温度と AVHRR/ 2 デー夕より 推定された積雪の無い薄水の水厚の関係を調べた結 果, 水平偏波が水厚の増加にともなって輝度温度が高 くなることが明らかになった。その結果, NASA-St. では, 薄水の水厚に依存した海水密接度の過小評価が 生じることが分かった。

通常，マイクロ波放射計デー夕を用いた海水密接度 推定アルゴリズムの評価は, 海水が海洋上に存在しそ れが観測視野内を全て覆っていれば，氷の厚さによら ず海水密接度 $100 \%$ という考えのもとで行っている。し 
かし, 熱収支の側面から大気・海水・海洋間の熱収支 を考之た場合, 薄水の厚さと大気への熱輸送量には負 の関係がある。このことから熱収支を推定することを 目的とする場合には, 薄水の密接度の算定にその水厚 の違いを加味した方がよいとも考えられる。今後は, 本論文で得られた結果から, 全球の薄水域における氷 厚推定手法及び薄水域の水厚を加味した海水密接度推 定手法の検討を行う予定である。

\section{謝辞}

サロマ湖上での観測ではサロマ湖養殖漁業協同組 合, 宇宙開発事業団, リモートセンシング技術センター の方々をはじめ, 実験に参加された多くの方々にご協 力頂いた。スペクトル観測の際には気象研究所の青木 輝夫氏に多大なるご協力を頂いた。また，オホーツク 海全域を含む NOAA/AVHRR/ 2 画像は北見工業大 学物理研究室より提供頂いた。ここに記して厚くお礼 申し上げる。なお，サロマ湖上でのスペクトル観測は 宇宙開発事業団との共同研究「AMSSによるADEOS II/GLI 雪水検証校正観測」の一部として行われたもの である。

（受付日2001.7.5, 受理日2001.9.11）

\section{参考文献}

1 ) Zwally, H.J., Comiso, J.C., Parkinson, C.L., Campbell, W.J., Carsey, F.D. and Gloersen, P. : Antarctic Sea Ice, 1973-1976 Satellite Passive Microwave Observations, NASA SP-459, Washington, NASA Scientific and Technical Information Branch, 206pp, 1983.

2) Gloersen, P., Parkinson, C.L., Cavalieri, D.J., Comiso, J.C. and Zwally, H.J. : Spatial distribution of trends and seasonality in the hemispheric sea covers: 1978-1996, J. Geophys. Res., 104, 20827-20835, 1999.

3 ) Comiso, J.C., Cavalieri, D.J., Parkinson, C.L., and Gloersen, P.: Passive microwave algorithms for sea ice concentration: A comparison of two techniques, Remote Sens. Environ., 60, 357-384, 1997.

4 ）奈良部隆行, 長 幸平, 下田陽久, 坂田俊文: NOAA/AVHRR データとの比較による SSM/I 海 氷密接度推定アルゴリズムの検証（その 2 ), 日本リ モートセンシング学会第28回学術講演会論文集, 157-158, 2000.
5 ) Maykut, G.A. : Energy exchange over young sea ice in the central arctic, J. Geophys. Res., 83, 3646-3658, 1978.

6 ）長 幸平, 青木 久, 下田陽久, 坂田俊文, 立花 義裕：衛星搭載マイクロ波放射計によるオホーツク 海の海水分布変動解析, 日本リモートセンシング学 会第21回学術講演会論文集, 1996.

7 ) Parkinson, C.L., Cavalieri, D.J., Gloersen, P., Zwally, H.J., and Comiso, J.C.: Arctic sea ice extents, areas, and trends, 1978-1996, J. Geophys. Res., 104, 20837-20856, 1999.

8 ）気象庁：オホーツク海及び周辺海域の海水状況, 気象庁海水観測資料，18，29-39，2000.

9 ) Svendsen, E., Kloster, K., Farrelly, B., Johannessen, O.M., Johannessen, J.A., Campbell, W.J., Gloersen, P., Cavalieri, D.J., and Matzler, C. : Norwegian Remote Sensing Experiment : Evaluation of the Nimbus 7 Scanning Multichannel Microwave Radiometer for sea ice research, J. Geophys. Res., 88, 2781-2792, 1983.

10) Cavalieri, D.J., and Gloersen, P.: Determination of sea ice parameters with the NIMBUS 7 SMMR, J. Geophys. Res., 89, 5355-5369, 1984.

11) Comiso, J.C.: Characteristics of Arctic winter sea ice from satellite multispectral microwave observations. J. Geophys. Res., 91, 975-994, 1986.

12) Gloersen, P., and Cavalirei, D.J. : Reduction of weather effects in the calculation of sea ice concentration from microwave radiances, J. Geophys. Res., 91, 3913-3919, 1986.

13) Cavalieri, D.J. : NASA Sea Ice Validation Program for the Defense Meteorological Satellite Program Special Sensor Microwave Imager: Final Report. NASA Technical Memorandum 104559, 126pp, 1992.

14) Wensnahan, M., Maykut, G.A., Grenfell, T.C., and Winebrenner, D.P.: Passive microwave remote sensing of thin sea ice using principal component analysis. J. Geophys. Res., 98, 1245312468, 1993.

15) Cavalieri, D.J.: A microwave technique for mapping thin sea ice, J. Geophys. Res., 99, 1256112572, 1994.

16) Comiso, J.C.: SSM/I Sea Ice Concentrations Using the Bootstrap Algorithm, NASA Reference Publication 1380, Maryland, NASA Center for AeroSpace Information, 57pp, 1995. 
17) Smith, D.: Extraction of winter total sea-ice concentration in the Greenland and Barents seas from SSM/I, Int. J. Remote Sensing, 17, 26252646, 1996.

18) National Snow and Ice Data Center, Sea Ice Products, http://nsidc.org/seaice/

19) National Snow and Ice Data Center, DMSP SSM/I Daily and Monthly Polar Gridded Sea Ice Concentrations, http://nsidc.org/NSIDC/CATALOG/ENTRIES/nsi-0002.html

20) Martin, S., Drucker, R., and Yamashita, K.: The production of ice and dense shelf water in the Okhotsk Sea polynyas, J. Geophys. Res., 103, 27771-27782, 1998.

21) Steffen, K. : Energy flux density estimation over sea ice based on satellite passive microwave measurements, Ann. Glaciol., 15, 178-183, 1991.

22) National Snow and Ice Data Center, DMSP SSM/I Brightness Temperature and Sea Ice Concentration Grids for the Polar Regions User's Guide. Second revised edition, Colorado, NSIDC Distributed Active Archive Center, 110pp, 1996.

23) Kidwell, K.B.: NOAA POLAR ORBITER DATA USERS GUIDE (Nov. 1998 revision), NOAA Natl. Envi. Satellite, Data, and Inf. Serv., Maryland, 1998.

24) Massom, R., and Comiso, J.C.: The classification of Arctic Sea ice types and the determination of surface temperature using advanced very high resolution radiometer data, J. Geophys. Res., 99, 5201-5218, 1994.

25) Yamanouchi, T., and Kawaguchi, S.: Cloud distribution in the Antarctic from AVHRR data and radiation measurements at the surface, Int. J. Remote Sens., 13, 111-127, 1992.

26) Wan, Z., and Dozier, J. : Land-surface temperature measurement from space: Physical principles and inverse modeling, IEEE Trans. Geosci. Remote Sens., 27, 268-277, 1989.

27) Paltridge, G.W., and Mitchell, R.M. : Atomospheric and viewing angle correction of vegetation indices and grassland fuel moisture content derived from NOAA/AVHRR, Remote Sens. Environ., 31, 121-135, 1990.

28) Wadhams, P., Davis, N.R., Comiso, J.C., Kutz, R., Crawford, J., Jackson, G., Krabill, W., Sear, C. B., Swift, R., and Tucker III, W.B. : Concurrent remote sensing of Arctic sea ice from submarine and aircraft, Int. J. Remote Sens., 12, 1829-1840, 1991.

29) Hudson, R. : Annual measurement of sea-ice thickness using an upward-looking sonar, Nature, 344(6262), 135-137, 1990.

30）西尾文彦，土田幸子：才ホーツク海の海水厚の測 定と変動, 釧路論集 : 北海道教育大学釧路分校研究 報告， 30，63-86， 1998 .

31）谷口悠司, 中山雅茂, 長 幸平, 下田陽久, 坂田 俊文： 3 次元画像計測による海水厚測定に関する研 究, 第23回極域気水圈シンポジウムプログラム・講 演要旨, 60-61, 2000.

32) Haas, C., Gerland, S., Ericken, H. and Miller, H. : Comparison of sea-ice thickness measurements under summer and winter conditions in the Arctic using a small electromagnetic induction device, Geophysics, 62, 749-757, 1997.

33) Allison, I. : East antarctic sea ice: albedo, thickness distribution, and snow cover, J. Geophys. Res., 98, 12417-12429, 1993.

34) Perovich, D.K., and Grenfell, T.C.: A theoretical model of radiative transfer in young sea ice, $\mathrm{J}$. Glaciol., 28, 341-356, 1982.

35) Grenfell, T.C. : A theoretical model of the optical properties of sea ice in the visible and near infrared, J. Geophys. Res., 88, 9723-9735, 1983.

36) World Meteorological Organization, WMO sea -ice nomenclature, No. 259, 15, 1975.

37) Crocker, G.B. : A physical model for predicting the thermal conductivity of brine-wetted snow, Cold Regions Science and Technology, 10, 69-74, 1984.

38) Onstott, R.G.: SAR and Scatterometer Signatures of Sea Ice, Microwave Remote Sensing, American Geophysical Union, Washington, Chapter5, 87, 1992.

39）中山雅茂, 長 幸平, 下田陽久, 坂田俊文, 谷川 朋範，西尾文彦：オホーツク海一年水の観測に有効 なマイクロ波放射計の周波数帯.偏波の検討, 雪水, 62, 523-535, 2000.

40) Enomoto, H.: Observation of thin ice area in the Okhotsk Sea and impacts for climatological study, 日本リモートセンシング学会誌, 16, 100-111, 1996. 